\title{
INFLUENCE OF SEAWATER SALINITY ON CORROSION OF HULL STRUCTURAL STEEL
}

\author{
Paweł Zagożdżon, Robert Starosta \\ Gdynia Maritime University, Faculty of Marine Engineering \\ Marine Maintenance Department \\ Morska Street 81-87, 81-225 Gdynia, Poland \\ tel.:+48585586241,fax: +48585586399 \\ e-mail:pawel971996@wp.pl,r.starosta@wm.umg.edu.pl
}

\begin{abstract}
Hulls of ships are often made of steel, which are produced under the supervision of classification societies. Usually, the hull steel of ordinary strength category A is used for the ship's shell (the yield strength is $235 \mathrm{MPa}$ and the impact strength $27 \mathrm{~J}$ at $20^{\circ} \mathrm{C}$ ). Vessels sail in sea areas with various levels of salinity and thus with different corrosiveness. The average salinity of the seas is taken as 3.5\% content of sodium chloride. This article presents the results of corrosion tests of S235 JRG1 steel in an aqueous solution in which the mass fraction of sodium chloride was: $0.7 \%, 1.4 \%, 2.2 \%, 2.8 \%, 3.5 \%$ and $4.2 \%$. Corrosion tests were performed using the potentiodynamic method. As parameters characterizing the corrosion properties of the tested steel, the corrosion current density and corrosion potential were assumed. Statistically significant influence of seawater salinity on the corrosion properties of hull structural steel of ordinary strength of category A was found. The highest value of the corrosion current density was observed in the solution containing $3.5 \% \mathrm{NaCl}$ mass fraction was observed. In seawater with a sodium chloride content in the range of 0.7 to $3.5 \%$, an increase in the value of the corrosion current density was observed, along with the increasing share of $\mathrm{NaCl}$. In seawater with higher salinity, the corrosion rate was reduced. The corrosion potential of S235JRG1 steel decreases with the NaCl content in the corrosive solution. The susceptibility of this material to corrosion in seawater increased.
\end{abstract}

Keywords: hull structural steel, corrosion, potentiodynamic test, seawater

\section{Introduction}

Hull structural steel is used for ship construction elements and is subject to the supervision of classification societies. These steels are also manufactured in accordance with the requirements of these societies and under their supervision. Such supervision involves the approval of steel manufacturing technologies and measurements and tests to ensure guaranteed material quality.

Hull structural steel with normal strength have a guaranteed minimum yield strength $Y S=235 \mathrm{MPa}$ and tensile strength $U T S=400 \mathrm{MPa}$. Hull structural steel structural of normal strength are divided into four categories - A, B, D, E, differing in chemical composition, deoxidation, delivery status and, above all, fracture toughness criteria. This criterion, based on the Charpy $\mathrm{V}$ impact strength test, is $27 \mathrm{~J}$ on longitudinal samples at different test temperatures, depending on the steel category (Tab. 1) $[4,5]$.

Tab. 1. The mechanical properties of the hull structural steel of normal strength, for sheet thickness below $50 \mathrm{~mm}$ [5]

\begin{tabular}{|c|c|c|c|c|c|c|}
\hline \multirow{2}{*}{$\begin{array}{c}\text { Steel } \\
\text { category }\end{array}$} & $Y S_{\text {min. }}$ & $U T S$ & $E L_{\text {min. }}$ & \multicolumn{3}{|c|}{ Impact strength $K V_{\text {min. }}$} \\
\cline { 2 - 7 } & {$[\mathrm{MPa}]$} & {$[\mathrm{MPa}]$} & {$[\%]$} & Sample temperature $\left[{ }^{\circ} \mathrm{C}\right]$ & {$[\mathrm{J}](\mathrm{L})$} & {$[\mathrm{J}](\mathrm{T})$} \\
\hline A & & & & - & - & - \\
B & \multirow{2}{*}{235} & \multirow{2}{*}{$400-520$} & 22 & 0 & 27 & 20 \\
D & & & & -20 & 27 & 20 \\
E & & & & -40 & 27 & 20 \\
\hline
\end{tabular}


where:

$Y S_{\text {min. }}$ - the minimum value of the yield stress,

UTS - permissible range of tensile strength values,

$E L$ min. - permissible minimum value of relative elongation (strain) ratio after bursting, determined on non-proportional samples with rectangular cross-section,

$K V_{\text {min. }}$ - desired he average value of the impact energy,

(L) - for sample cut in the direction of rolling,

(T) - for sample cut in a direction perpendicular to the direction of rolling.

The hulls of ships are mainly constructed from steel of categories A and B, while steels of category $\mathrm{D}$, and in particular $\mathrm{E}$, are used only for the most responsible, highly loaded structural elements in the middle part of the hull, affecting the safety of the entire structure.

The weldability of hull structural steel is guaranteed by limiting the carbon content and carbon equivalent $C E V$. For steel with normal strength, the $C E V$ value should not exceed $0.40 \%$. The formula used to determine the value of carbon equivalent for the normal strength hull steel is $[4,5]$ :

$$
C E V=\mathrm{C}+\frac{\mathrm{Mn}}{6}
$$

where:

$C E V$ - carbon equivalent factor,

$\mathrm{C}$ - the mass fraction of carbon in steel [\%],

Mn - mass fraction of manganese in steel [\%].

After agreement with the classification society instead of factor of carbon equivalent, $C E V$, can be determined by susceptibility to cold cracking factor, $P_{\mathrm{cm}}$. The value of the $P_{\mathrm{cm}}$ coefficient may be determined based on the results of the melting analysis, according to the formula [5]:

$$
P_{c m}=\mathrm{C}+\frac{\mathrm{Ni}}{60}+\frac{\mathrm{Si}}{30}+\frac{\mathrm{Mn}+\mathrm{Cu}+\mathrm{Cr}}{20}+\frac{\mathrm{Mo}}{15}+\frac{\mathrm{V}}{10}+5 \mathrm{~B},
$$

where:

$P_{c m}$ - carbon equivalent factor,

$\mathrm{C}, \mathrm{Ni}, \mathrm{Si}, \mathrm{Mn}, \mathrm{Cu}, \mathrm{Cr}, \mathrm{Mo}, \mathrm{V}, \mathrm{B}$ - mass fraction of alloying elements in steel [\%].

Normal strength hull structural steel category A is supplied in a raw state (without heat treatment) or normalized or hot-rolled, often without impact test, although the manufacturing technology and chemical composition as to satisfy the criterion of $27 \mathrm{~J}$ at $20^{\circ} \mathrm{C}$. In addition, sheets made of this steel can be supplied in semi-finished state, and profiles up to $12.5 \mathrm{~mm}$ thick also in an effervescent state, based on arrangements with the classification society. In addition, sections made of this steel can contain up to $0.23 \%$ carbon $[4,5]$.

Category B hull structural steel is usually supplied in the hot-rolled condition as semi-killed or killed down with a guaranteed impact strength of $27 \mathrm{~J}$ at $0^{\circ} \mathrm{C}$. Some classification societies do not require impact testing up to a thickness of $25 \mathrm{~mm}$ for acceptance tests. When an impact test is performed, the minimum manganese content can be reduced from 0.80 to $0.60 \%$ [5].

The category D hull structural steel is delivered in a de-oxidised state. Only de-oxidised steel by silicon may be used for sheet thicknesses up to $25 \mathrm{~mm}$, while above this value an additional use of aluminium in an amount of at least $0.015 \%$ is required to grain refinement. Category D steels up to a thickness of $35 \mathrm{~mm}$ can be supplied without heat treatment in the hot rolled state, while more than $35 \mathrm{~mm}$ are required to normalize, controlled rolling or thermo-mechanical rolling [5].

The category E hull structural steel is supplied as de-oxidised (killed) state, fine-grained, with a reduced carbon content $(\mathrm{C}<0.18 \%)$, compared to other steel categories of normal strength. For the whole range of steel sheet thicknesses, heat treatment in the form of normalization or thermomechanical rolling applies. The impact test is used to a rolled semi-finished product from which the sheets are made [5]. 
Corrosion in steel under constant immersion in seawater has electrochemical nature. Due to some of the features of this environment, resulting already from the chemical composition itself and the properties of seawater, this corrosion is characterized by high activity of corrosion cells. This phenomenon results from the significant electrical conductivity of seawater, which is the cause of low inhibition of ohmic cell operation. In this situation, corrosion occurs both as a result of the work of micro-cells (resulting, for example, as a result of non-homogeneity of the metal surface), as well as macro-cells formed by the contact of two metals (e.g. corrosion of the steel hull plating under the influence of a brown propeller). There is a slight role in inhibiting an anodic corrosion process of most structural metals. This is caused by the presence of an extremely aggressive chloride ion, which destroys the protective passive layers. The corrosion rate of steel in seawater is determined by the inhibition of the cathodic process. Corrosion in seawater running is almost entirely with oxygen depolarization. Hence, the velocity of oxygen supply to the corrosive surface is the main controlling factor. Corrosion of steel in seawater is characterized by an increased tendency towards non-uniformity. The maximum depth of corrosion pits can exceed 3 to 4 times the size of the linear corrosion index $[3,6,7,9]$.

In ordinary hull structure steels are depending on the condition of delivery, there may be the following structural components: ferrite, perlite, tertiary cementite. The microstructure of normal strength hull structural steel is shown in Fig. 1 [2].

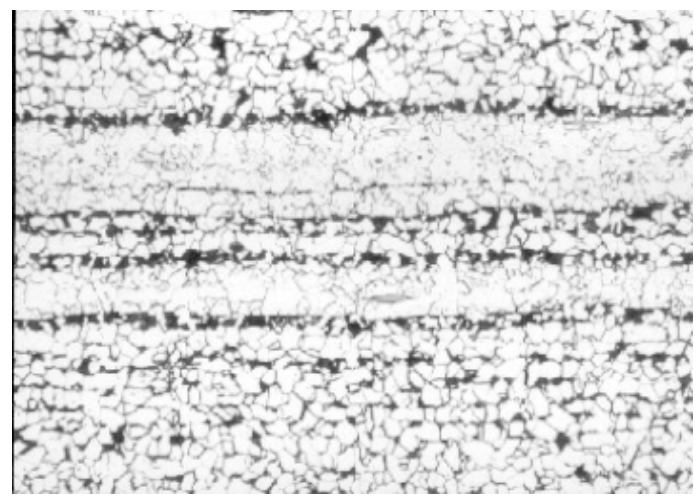

Fig. 1. The ferrite-perlite structure of the normal strength hull structural steel [2]

This article presents the results of potentiodynamic corrosion tests, the aim of which was to assess the impact of seawater salinity on corrosion of hull steel of ordinary strength category A.

\section{Testing methods}

The corrosion test specimens were made of normal strength hull structural steel of category A (S235 JRG1 - EN 10025) with the chemical composition: $0.2 \% \mathrm{C}, 1.4 \% \mathrm{Mn}, 98.4 \% \mathrm{Fe}$. The corrosion properties of S235JRG1 steel were tested in aqueous $\mathrm{NaCl}$ solution (the so-called replacement seawater). The mass fraction of sodium chloride in the corrosive solution was: $0.7 \%$, $1.4 \%, 2.1 \%, 2.8 \%, 3.5 \%, 4.2 \%$

The corrosion resistance of steel was estimated by electrochemical potentiodynamic (polarization) method. Electrochemical polarization studies belong to the classical methods of corrosion testing. It is well understood and relatively frequently used. The rate of measurement is high compared to the gravimetric methods. Electrochemical polarization allows both estimation of the instantaneous rate of corrosion and determination of the nature of the processes involved. The aim of studies of the polarization is to analyse the corrosion current with the aid of the following formula [10]:

$$
j=j_{\text {corr }}\left[\left(1-\frac{j_{a}}{j_{d a}}\right) \exp \left(\frac{2.3\left(E-E_{\text {corr }}\right)}{b_{a}}\right)-\left(1-\left|\frac{j_{c}}{j_{d c}}\right|\right) \exp \left(\frac{-2.3\left(E-E_{\text {corr }}\right)}{b_{c}}\right)\right],
$$


where:

$j \quad-$ current density of polarization $\left[\mathrm{mA} / \mathrm{cm}^{2}\right]$,

$j_{\text {corr }}-$ corrosion current density $\left[\mathrm{mA} / \mathrm{cm}^{2}\right]$,

$E \quad$ - polarization potential $[\mathrm{mV}]$,

$E_{\text {corr }}$ - corrosion potential [mV],

$b_{a} \quad$ - anodic Tafel constant $[\mathrm{mV}]$,

$b_{c} \quad$ - cathodic Tafel constant [mV].

$j_{a} \quad$ partial anodic current density $\left[\mathrm{mA} / \mathrm{cm}^{2}\right]$,

$j_{c} \quad-$ partial cathodic current density $\left[\mathrm{A} / \mathrm{cm}^{2}\right]$,

$j_{d a} \quad$ - limiting anodic current density $\left[\mathrm{mA} / \mathrm{cm}^{2}\right]$,

$j_{d c} \quad$ - limiting cathodic current density $\left[\mathrm{mA} / \mathrm{cm}^{2}\right]$.

The polarization measurements in a three-electrode cell were performed. The test sample, platinum counter-electrode (CE), saturated calomel electrode (SCE) were placed in the vessel, in which was $500 \mathrm{ml}$ of $\mathrm{NaCl}$ solution at ambient temperature. The samples were exposed to the electrolyte for one hour. During the study, the ATLAS 0531 potentiostat was used. The polarization curves of $j=f(E)$ in the range of $E_{c o r r} \pm 150 \mathrm{mV}$ were recorded. Rate of change of the potential, in all cases, was $10 \mathrm{mV} / \mathrm{min}$. In order to calculate the value of parameters characterizing the properties of corrosion (corrosion current density, corrosion potential, Tafel constants, limiting current density) of the test material the "Elfit - corrosion polarization data fitting program" computer program was used. This program calculates the corrosion process parameters of equation (3). To assess the impact of seawater salinity on the corrosion resistance of the normal hull steel, the calculated values of the density of the corrosive current and corrosive potential were used $[1,8]$.

The 10 repetitions were made measurements of polarization normal strength steel hull category A, for each $\mathrm{NaCl}$ concentration of corrosive solution used.

\section{Results}

In Fig. 2, in the Evans chart, exemplary polarization curves obtained as a result of current density $(j)$ measurement as a function of potential $(E)$ change of the electrode being investigated (S235 JRG1 steel), in a corrosive environment with variable $\mathrm{NaCl}$ concentration are presented.

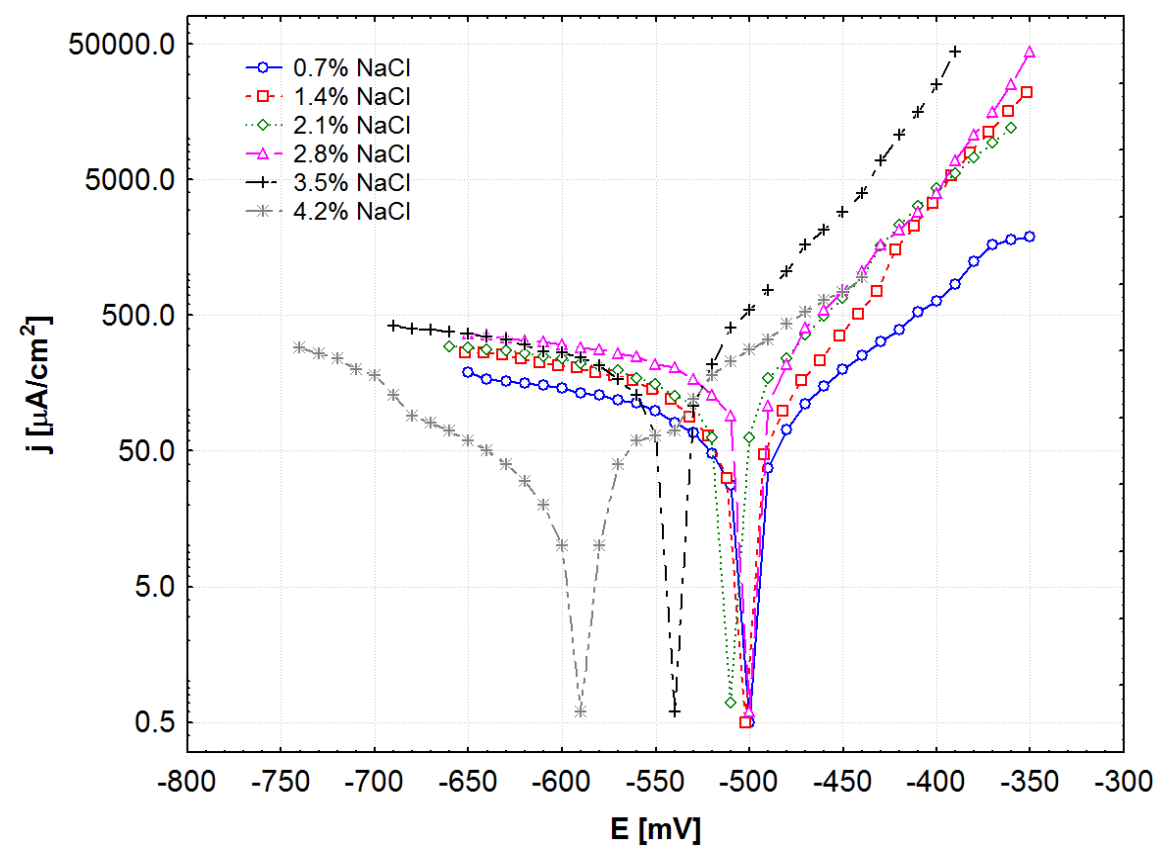

Fig. 2. Exemplary polarization plots $j=f(E)$ for S235JRG1 steel in aqueous environment with various degree of $\mathrm{NaCl}$ mass fraction 


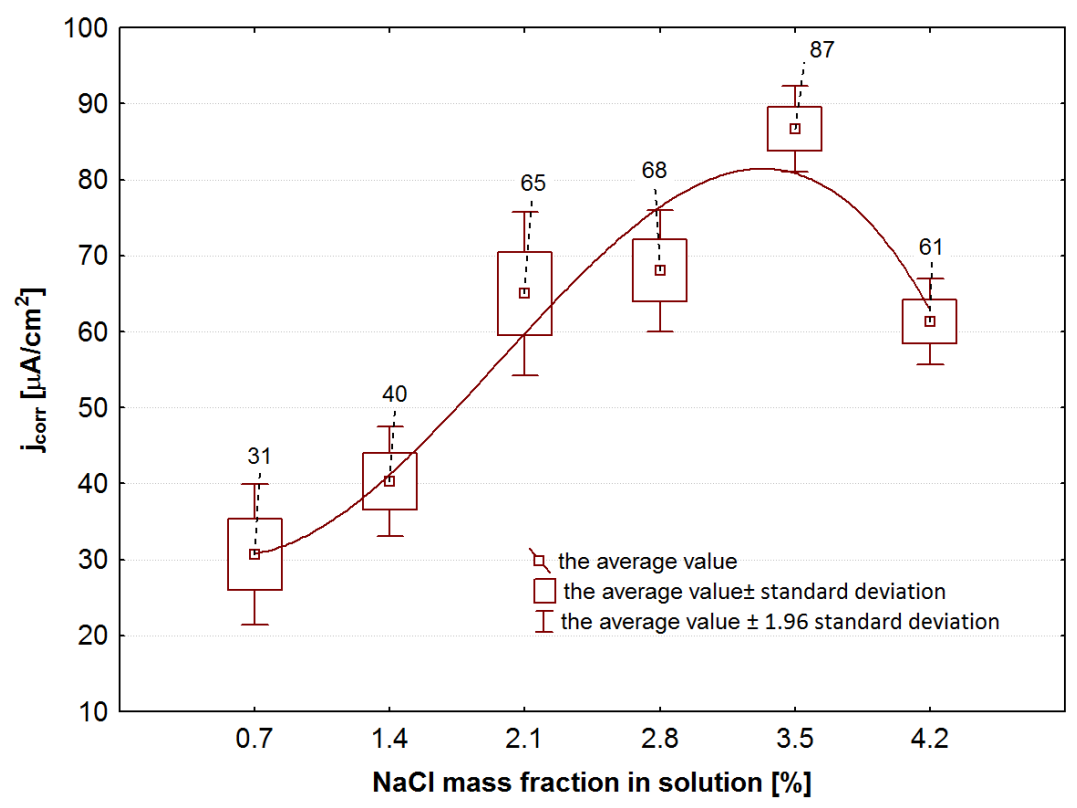

Fig. 3. Effect of $\mathrm{NaCl}$ concentration on the corrosion current density value of S235 JRG1 steel in seawater environment

Figure 3 presents the results of the basic statistical analysis (mean value, standard deviation, confidence interval) for the calculated results of the corrosion current density $\left(j_{\text {corr }}\right)$ value measurement. There is a very high positive linear correlation $(r=0.77)$ between the density of the corrosion current and the mass fraction of sodium chloride in the corrosive solution. Corrosion current density values ranged from $31 \mathrm{~mA} / \mathrm{cm}^{2}$ to $87 \mathrm{~mA} / \mathrm{cm}^{2}$. The smallest $j_{\text {corr }}$ value in the case of S235JRG1 steel exposed in $0.7 \% \mathrm{NaCl}$ environment was observed. The highest value of the corrosion current density was found for an aqueous solution containing $3.5 \% \mathrm{NaCl}$ was found. The rate of corrosion of category A, hull structural steel increases with increasing the concentration of $\mathrm{NaCl}$ in aqueous corrosive. In this case, the rate of corrosion processes is associated with an increase in the ionic conductivity of the solution along with the degree of salinity of seawater because of a drop in the value of the solution resistance and the polarization resistance.

The increase in the value of corrosion current density occurred in aqueous solutions containing a mass fraction of $\mathrm{NaCl}$ in the range from $0.7 \%$ to $3.5 \%$. In a solution, containing $4.2 \% \mathrm{NaCl}$ there was a decrease in the value of the corrosion current density compared to the $j_{\text {corr }}$ value for the environment containing 3.5\% sodium chloride. The observed decrease in the value of the corrosion current density is related to the phenomenon occurring in solutions of neutral salts. In aqueous solutions, the solubility of gases, including oxygen, decreases with increasing concentration of neutral salts. In seawater, the $\mathrm{pH}$ of which is alkaline $(\mathrm{pH}=7.2-8.4)$, oxygen is required for corrosion during the reduction reaction. Thus, the electrode reaction occurring on the cathode of the corrosion cell is inhibited. These results are, among other things, in a decrease in corrosive potential (Fig. 4).

Due to the relatively large spread of the obtained values of corrosion current density, for individual corrosive environments, as evidenced by the values of standard deviations (Fig. 3), statistical non-parametric significance tests for many groups of independent variables were performed (Kruskal-Wallis and median tests). The null hypothesis was formulated as follows: the value of $j_{\text {corr }}$ does not depend on the concentration of $\mathrm{NaCl}$ in the corrosive solution. The results of non-parametric significance tests for the $\mathrm{j}_{\text {corr }}$ variable are presented in Tab. 2. The obtained values of the Kruskal-Wallis test $H=52.96$ and the median test $X^{2}=39.59$, at the assumed significance level of $\alpha=0.05$ allow to reject the null hypothesis. Thus, with a $95 \%$ probability, it can be concluded that the corrosion rate of the steel tested depends on the salinity of seawater. The prediction of the corrosion current density values for S235 JRG steel can be made using the regression equation (4) (value of the determination coefficient for the equation $R^{2}=0.93$ ): 


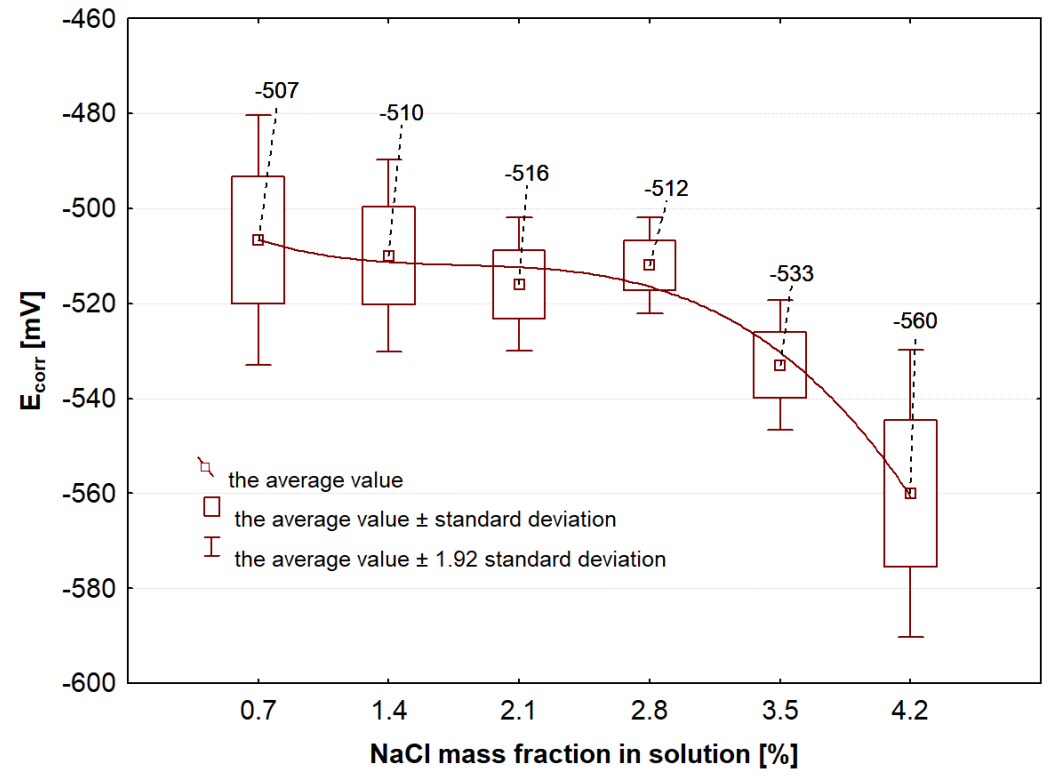

Fig. 4. Effect of $\mathrm{NaCl}$ concentration on the potential corrosion current density value of S235 JRG1 steel in seawater environment

Tab. 2. Results of significance non-parametric tests for independent variables: corrosion current density (j $\left.j_{\text {corr }}\right)$ and corrosion potential $\left(E_{\text {corr }}\right.$ ) of S235 JRG1 steel in solutions with variable concentration of $\mathrm{NaCl}$

\begin{tabular}{|c|c|c|}
\hline \multirow{2}{*}{ Variable } & \multicolumn{2}{|c|}{ The value of the test } \\
\cline { 2 - 3 } & Kruskal-Wallis test, $H$ & median test, $X^{2}$ \\
\hline$j_{\text {corr }}\left[\mu \mathrm{A} / \mathrm{cm}^{2}\right]$ & 52.96 & 39.59 \\
\hline$E_{\text {corr }}[\mathrm{mV}]$ & 41.58 & 29.17 \\
\hline
\end{tabular}

where:

$$
j_{\text {corr }}=-4.958 \% \mathrm{NaCl}^{3}+29.15 \% \mathrm{NaCl}^{2}-29.33 \mathrm{NaCl}+38.78
$$

$j_{\text {corr }} \quad-$ corrosion current density $\left.\mu \mathrm{A} / \mathrm{cm}^{2}\right]$,

$\% \mathrm{NaCl}$ - mass fraction of sodium chloride in a corrosive solution [\%].

Depending on the proportion of sodium chloride in the corrosion solution, the average value of corrosion potential was in the range from -560 to $-507 \mathrm{mV}$. A very high correlation between saltwater salinity and corrosion potential was found. This dependence is inversely proportional $(r=-0.87)$. The value of corrosion potential decreases as a result the increasing of $\mathrm{NaCl}$ concentration in the corrosive solution. The decreasing $E_{c o r r}$ value is connected on the one hand to the extenuation of the reduction reaction and on the other hand to the faster depolarization of the anode. Non-parametric significance tests showed that $E_{c o r r}$ changes are statistically significant at the assumed level of $\alpha=0.05$ (Tab. 2).

The prediction of the corrosion potential of the S235JRG1 steel in the seawater environment can be made using the following regression equation $\left(R^{2}=0.97\right)$ :

$$
E_{\text {corr }}=-3.28 \% \mathrm{NaCl}^{3}+17.6 \% \mathrm{NaCl}^{2}-32.6 \mathrm{NaCl}-491.2,
$$

where:

$E_{\text {corr }} \quad$ - corrosion potential $\left.\mu \mathrm{A} / \mathrm{cm}^{2}\right]$,

$\% \mathrm{NaCl}$ - mass fraction of sodium chloride in a corrosive solution [\%].

\section{Conclusions}

- Statistically significant influence of seawater salinity on the corrosion properties of hull structural steel of ordinary strength of category A was found. 
- The highest value of the corrosion current density was observed in the solution containing $3.5 \% \mathrm{NaCl}$ mass fraction was observed.

- In seawater with a sodium chloride content in the range of 0.7 to $3.5 \%$, an increase in the value of the corrosion current density was observed, along with the increasing share of $\mathrm{NaCl}$. In seawater with higher salinity, the corrosion rate was reduced.

- The corrosion potential of S235JRG1 steel decreases with the $\mathrm{NaCl}$ content in the corrosive solution. The susceptibility of this material to corrosion in seawater increased.

\section{References}

[1] Charchalis, A., Starosta, R., Effect of finishing on the corrosion properties of flame sprayed $\mathrm{Ni}-5 \% \mathrm{Al}$ and $\mathrm{Ni}-5 \% \mathrm{Al}_{-} \mathrm{Al}_{2} \mathrm{O}_{3}$ coatings, Journal of KONES Powertrain and Transport, Vol. 21, No. 4, pp. 29-36, 2014.

[2] Cicholska, M., Czechowski, M., Materiałoznawstwo okrętowe, Wydawnictwo Akademii Morskiej, Gdynia 2013.

[3] Jurczak, W., Ochrona antykorozyjna morskich jednostek pływajacych, TTS Technika Transportu Szynowego, Vol. 23, No. 12, pp. 310-316, 2016.

[4] Przepisy Klasyfikacji i budowy statków morskich. Część II, kadtub, Wyd. Polski Rejestr Statków, Gdańsk 2018.

[5] Przepisy Klasyfikacji i budowy statków morskich. Część IX, materiały i spawanie, Wyd. Polski Rejestr Statków, Gdansk 2018.

[6] Refait, Ph., Grolleau, A. M., Jeannin, M., Francois, E., Sabot, R., Localized corrosion of carbon steel in marine media: Galvanic coupling and heterogeneity of the corrosion product layer, Corrosion Science, Vol. 111, pp. 583-595, 2016.

[7] Refait, Ph., Grolleau, A. M, Jeannin, M., Francois, E., Sabot, R., Corrosion of mild steel at the seawater/sediments interface: Mechanisms and kinetics, Corrosion Science, Vol. 130, pp. 76-84, 2018.

[8] Starosta, R., The quantitative analysis of the effect of the porosity, the volume of fraction of reinforcing phase and the thermal spraying methods, on corrosion properties of composite coatings in marine environment, Journal of KONES Powertrain and Transport, Vol. 23, No. 1, pp. 321-327, 2016.

[9] Qu, Q., He, Y., Wang, L., Xu, H., Li, L., Chen, Y., Ding, Z., Corrosion behavior of cold rolled steel in artificial seawater in the presence of Bacillus subtilis C2, Corrosion Science, Vol. 91, pp. 321-329, 2015.

[10] Woźniak, P., Starosta, R., Corrosive properties of multi -groove pads hardfacing with the $M I G$ method, Proceedings of 27th International Conference on Metallurgy and Materials, pp. 910-917, Brno 2018.

Manuscript received 26 March 2019; approved for printing 27 June 2019 